\title{
Recent advances in understanding synaptic abnormalities in
}

\section{Rett syndrome [version 1; peer review: 2 approved]}

\author{
Michael V. Johnston(iD1-4, Mary E. Blue1,2,5, Sakkubai Naidu²,6
}

${ }^{1}$ Developmental Neuroscience Laboratory, Kennedy Krieger Institute, Johns Hopkins University School of Medicine, Baltimore, MD, USA

${ }^{2}$ Department of Neurology, Johns Hopkins University School of Medicine, Baltimore, MD, USA

${ }^{3}$ Department of Pediatrics, Johns Hopkins University School of Medicine, Baltimore, USA

${ }^{4}$ Department of Physical Medicine and Rehabilitation, Johns Hopkins University School of Medicine, Baltimore, MD, USA

${ }^{5}$ Department of Neuroscience, Johns Hopkins University School of Medicine, Baltimore, MD, USA

${ }^{6}$ Department of Neurogenetics, Kennedy Krieger Institute, Johns Hopkins University School of Medicine, Baltimore, MD, USA

V1 First published: 22 Dec 2015, 4(F1000 Faculty Rev):1490

https://doi.org/10.12688/f1000research.6987.1

Latest published: 22 Dec 2015, 4(F1000 Faculty Rev):1490

https://doi.org/10.12688/f1000research.6987.1

\section{Abstract}

Rett syndrome is an extremely disabling X-linked nervous system disorder that mainly affects girls in early childhood and causes autism-like behavior, severe intellectual disability, seizures, sleep disturbances, autonomic instability, and other disorders due to mutations in the MeCP2 (methyl CpG-binding protein 2) transcription factor. The disorder targets synapses and synaptic plasticity and has been shown to disrupt the balance between glutamate excitatory synapses and GABAergic inhibitory synapses. In fact, it can be argued that Rett syndrome is primarily a disorder of synaptic plasticity and that agents that can correct this imbalance may have beneficial effects on brain development. This review briefly summarizes the link between disrupted synaptic plasticity mechanisms and Rett syndrome and early clinical trials that aim to target these abnormalities to improve the outcome for these severely disabled children.

\section{Keywords}

X-linked, Glutamate, Rett Syndrome

\section{Open Peer Review}

Approval Status

1 2

version 1

22 Dec 2015

Faculty Reviews are review articles written by the prestigious Members of Faculty Opinions. The articles are commissioned and peer reviewed before publication to ensure that the final, published version is comprehensive and accessible. The reviewers who approved the final version are listed with their names and affiliations.

1. Zhi-Qi Xiong, Shanghai Institutes for Biological Sciences, Chinese Academy of Sciences, Shanghai, China

2. Thierry Bienvenu, AP-HP, Laboratoire de Biochimie et Génétique Moléculaire, GH Cochin-Broca-Hôtel Dieu, Paris, France and Université Paris Descartes Paris, Institut Cochin, INSERM U1016, Paris, France Any comments on the article can be found at the 
end of the article.

Corresponding author: Michael V. Johnston (johnston@kennedykrieger.org)

Competing interests: The authors declare that they have no competing interests.

Grant information: This work was supported by FDA Grant 5RO1FD004247 and NIH-NICHD U54 HD079123.

Copyright: @ 2015 Johnston MV et al. This is an open access article distributed under the terms of the Creative Commons Attribution License, which permits unrestricted use, distribution, and reproduction in any medium, provided the original work is properly cited.

How to cite this article: Johnston MV, Blue ME and Naidu S. Recent advances in understanding synaptic abnormalities in Rett syndrome [version 1; peer review: 2 approved] F1000Research 2015, 4(F1000 Faculty Rev):1490

https://doi.org/10.12688/f1000research.6987.1

First published: 22 Dec 2015, 4(F1000 Faculty Rev):1490 https://doi.org/10.12688/f1000research.6987.1 


\section{Introduction}

Rett syndrome (RTT) is characterized by severe neurodevelopmental delay in psychomotor development that occurs predominantly in girls and is due to mutations in the gene on the $\mathrm{X}$ chromosome that codes for the transcription factor methyl CpG-binding protein $2(\mathrm{MECP} 2)^{1,2}$. MECP2 is a transcription factor and pleiotropic protein that regulates the expression of numerous genes, including brain-derived neurotrophic factor $(\mathrm{BDNF})^{3}$, and can mediate transcriptional activation, mRNA splicing, and posttranslational processing of microRNAs ${ }^{4,5}$. A phenotype similar to RTT has also been described in children with mutations in the CDKL5 and FOXG1 genes ${ }^{6,7}$. Girls with RTT often present with features similar to autism with little or no speech development, poor contact with others, and stereotyped movements, including characteristic repetitive hand-wringing movements ${ }^{8}$. Girls with RTT typically undergo a postnatal regression phase during the first 3 years after birth in which hand wringing, seizures, loss of hand use, and loss of expressive language emerge ${ }^{9,10}$. Clinicians who have seen patients with RTT are usually able to identify others because of their unique combination of physical and neurologic features. In addition to autistic features and hand-wringing movements, the characteristic behavioral abnormalities in RTT include severely erratic breathing while awake with periods of alternating hyperventilation, cyanosis and apnea, severe seizures and autonomic instability in heart rate and blood pressure, and changes in the color of the extremities consistent with sympathetic instability ${ }^{11}$. The incidence of sudden death is increased in girls with RTT $^{12}$. Developing synapses appear to be a special target of the disorder, and head circumference is usually normal at birth but then falls behind over the first year of life so that it falls into the microcephalic range ${ }^{9,13-16}$. Neuropathologic examination of brain tissue from older girls with RTT who have died has revealed that neurons are typically too close together, suggesting a stunting of axonodendritic development ${ }^{17,18}$. This hypothesis is supported by studies of nasal epithelium from girls with RTT compared with controls, which showed that the neurogenesis of olfactory receptor neurons is normal but their maturation is blocked at the point of formation of synapses with the olfactory bulb ${ }^{19}$.

\section{Role of excitatory synapse abnormalities in Rett syndrome}

Early studies of patients with RTT, including some who had not been tested for mutations in the MECP2 gene, suggested an abnormality of glutamate excitatory synapses ${ }^{18}$. For example, Hamberger et al..$^{20}$ and Lappalainen and Riikonen ${ }^{21}$ in the 1990s reported that cerebrospinal fluid from girls with RTT had concentrations of glutamate but not other amino acids that were more than twice as high as those of children without RTT. Blue et al. in 1999 reported the first autoradiographic study of glutamate and GABA receptors in postmortem brain tissue from nine girls with RTT and 10 female controls of different ages ${ }^{22}$. The authors reported that densities of $\mathrm{N}$-methyl-D-aspartate (NMDA) were elevated in the frontal lobe cortex in girls younger than 8 years of age but were significantly lower in girls older than 8 years without RTT $^{23}$. Similar age-related changes in glutamate receptors were observed in the basal ganglia. Horská et al. ${ }^{24}$ used magnetic resonance spectroscopy to demonstrate that glutamate was elevated in the cerebral cortex of younger girls (less than 8 years of age) with RTT, especially those with seizures, but reduced in older girls. These changes in levels of glutamate between younger and older girls correlate with the bi-phasic changes in the clinical condition of girls with RTT who have more clinical signs of excitatory activity, including seizures early in early childhood, but have reduced signs of excessive central nervous system activity later in childhood ${ }^{9}$. More recently, Blue et al. demonstrated similar age-related changes in the NMDA1 subtype in the Bird model of RTT in mice ${ }^{25}$. Taken together, the elevations in glutamate as well as in glutamate receptors in younger girls with RTT suggest that there is an abnormality of the normal homeostatic synaptic scaling by which post-synaptic receptors adjust upwards or downwards to maintain a stable level of neurotransmission ${ }^{26}$. This abnormality in synaptic function probably contributes to deficits in excitatory synaptic plasticity and enhanced excitability observed in mouse models of $\mathrm{RTT}^{27-30}$.

The pathophysiology of elevated glutamate in the face of elevated NMDA glutamate receptors in RTT is not clear. The major regulator of glutamate levels in and outside the synapse is the activity of glial glutamate transporters, which normally are activated when glutamate is released into the synapse ${ }^{31}$. Intra-synaptic levels of glutamate are thought to provide trophic influences on post-synaptic neurons, but glutamate flooding outside the synapse can activate excitotoxicity mediated by extra-synaptic NMDA receptors ${ }^{32}$. Maezawa and $\mathrm{Jin}^{33}$ reported that conditioned media obtained from Mecp2-null microglia from Mecp $2^{\text {tml.1Bird/+ }}$ mice $^{34}$ contain toxic levels of glutamate that is damaging to neural dendrites in vitro and this effect can be blocked by inhibiting glutaminase or glutamate receptors. Jin et al., using the same model of Mecp2 deficiency, reported that abnormal function of the SNAT1 glutamine transporter in microglia is associated with NMDA receptor-mediated neurotoxicity, mitochondrial dysfunction, and decreased viability of microglia ${ }^{35}$. Okabe et al. ${ }^{36}$ reported that astroglia from Mecp2null mice (Mecp $\left.2^{\text {tml.lBird/+ }}\right)$ had downregulation of glutamate transporters that could increase extracellular glutamate to toxic levels. Lioy et al. ${ }^{37}$ also reported that the restoration of wild-type MeCP2 in astrocytes of MeCP2-deficient mice $\left(\mathrm{Mecp} 2^{\text {Stop }}\right.$ ) restored normal dendritic morphology and increased levels of the excitatory glutamate transporter. We also found that cerebellar granule cells from Mecp2-null mice $\left(\right.$ Mecp $\left.^{\text {tml.libird/ }}\right)$ are more sensitive to cell death from hypoxia-ischemia and glutamate excitotoxicity compared with neurons from wild-type mice, suggesting that they also have intrinsic vulnerability to cell death ${ }^{38}$. These findings are consistent with the above-cited evidence of abnormal homeostatic synaptic scaling, which is expected to degrade normal excitatory neurotransmission and activity-dependent neuronal plasticity needed for learning and memory in RTT.

\section{Abnormal diurnal regulation of sleep and brain glutamate levels in MeCP2 deficiency}

Recently, the circadian sleep cycle in rodents has been associated with alterations in brain glutamate levels, with higher glutamate levels associated with wakefulness and sleep associated with a reduction in glutamate ${ }^{39}$. We applied the relatively new technology that can measure 24-hour continuous electroencephalogram (EEG) markers of sleep cycles and correlated them with biosensor measurement of in vivo glutamate concentrations ${ }^{40}$. We found that mice with a Mecp2 knockout mutation (Mecp $2^{\text {tm1.1Bird/+ }}$ ) had abnormal behaviors and remarkably abnormal sleep cycles with long periods 
of sleeplessness associated with very high relative concentrations of brain glutamate. These Mecp2-deficient mice also had elevated baseline levels of cortical glutamate measured with a separate colorimetric method in postmortem tissue. These data suggest that periods of sleep disturbance that are common in girls with RTT could be associated with enhanced glutamate neurotoxicity.

\section{Role of GABA-containing interneurons in Rett syndrome}

GABA (gamma-amino butyric acid) is the predominant inhibitory neurotransmitter in the brain and is used as a transmitter at approximately $15 \%$ of synapses, and there is ample evidence of its altered metabolism in the mice with Mecp2 deficiency. Chao et al. ${ }^{41}$ reported that the selective deletion of $\mathrm{MeCP} 2$ in GABA interneurons (Viaat-Mecp22/y mice) led to a reduction in the pre-synaptic release of GABA as well as autism-like stereotypies and RTT phenotypes in mice. Kang et al. ${ }^{42}$ reported that there is a significant locationspecific downregulation of synaptic GABA transporters in Mecp2 knockout mice $\left(\right.$ Mecp $\left.^{\text {tml.libird/ }+}\right)$, and El-Khoury et al. ${ }^{43}$ reported age- and region-specific reductions in function in GABAergic pathways in MeCP2-deficient mice (B6.129P2(c)-Mecp2. ${ }^{\text {tm1-1Bird }}$ ). These observations along with those from the glutamate system indicate that there is a shift in the balance between excitation and inhibition in favor of excitation, as has been suggested to occur in other autism spectrum disorders ${ }^{8,44}$.

One of the most interesting recent observations on the role of altered development in GABA and glutamate-containing neurons in mice with $\mathrm{MeCP} 2$ mutations relates to the link between MeCP2 and visual cortical plasticity ${ }^{45}$. Visual cortical plasticity associated with the occlusion of vision in one eye can be measured precisely in the laboratory in immature mice, and GABAergic interneurons play a critical role in this process ${ }^{46}$. Durand et al. reported that MeCP2null mice (Mecp $2^{\text {tm1.lBird/++}}$ ) have normal visual function early in the postnatal period but that visual acuity regresses after postnatal day $35-40$ and the cortex fell silent by postnatal day 55-60 ${ }^{47}$. Remarkably, this effect could be prevented by genetic deletion of the NMDA glutamate receptor subunit NR2A. He et al. also reported that the genetic conditional deletion of $\mathrm{MeCP} 2$ in GABAergic parvalbumin-expressing neurons prevented local circuit inhibitory functions required for experience-dependent visual cortical plasticity ${ }^{48}$. Krishnan et al. ${ }^{45}$ reported that the MeCP2 regulates the timing of the critical period of plasticity in the primary visual cortex. Kron et al $^{49}$ have also examined brain activity maps by using activation of the immediate early gene Fos and electrophysiology and found evidence of synaptic hyperexcitability in the cortical default mode network that was reduced by the administration of the NMDA channel blocking anesthetic ketamine. The results of these studies support the themes raised earlier in this discussion of RTT, namely that MeCP2 deficiency leads to excessive excitation versus inhibition and defective activity-dependent synaptic plasticity. Although ketamine can cause damage to developing neurons by excessively blocking the activity of NMDA receptors ${ }^{50}$, its use in RTT is intended to reduce excessive activity of NMDA receptors found in RTT to normal levels. Both too little and too much activity at NMDA receptors can damage the developing brain ${ }^{51}$.

\section{Potential new therapies based on advances in understanding Rett syndrome}

Several clinical studies are examining potential therapies for girls with RTT on the basis of the basic science insights from experiments on mice with $\mathrm{MeCP} 2$ deficiency. Naidu et al. launched a randomized open-label study of oral dextromethorphan, a competitive NMDA antagonist, for seizures and cognitive function in girls with RTT from 2008 to 2014 (ClinicalTrials.gov: NCT00593957). Results of this study suggest a significant improvement in a secondary outcome of receptive speech by using the Mullen Scales of Early Learning over the course of' 6 months but no change in seizures. Based on these promising preliminary data on cognition, Naidu et al. are carrying out a randomized double-blind study of dextromethorphan for girls with RTT which was started in January 2012 (ClinicalTrials.gov: NCT01520363) with support from the US Food and Drug Administration, and this study is still seeking subjects for enrollment. Other blockers of the NMDA receptor, including memantine and ketamine as mentioned above, are under discussion but have not been registered in ClinicalTrials.gov.

Published data are available on the administration of an active peptide of insulin-like growth factor 1 (IGF-1), which has been reported to be deficient in mice with Mecp2 deficiency ${ }^{52}$. IGF-1 activates tropomyosin receptor kinase $\mathrm{B}(\mathrm{TrkB})$ receptors and stimulates downstream signaling through the PI3K, AKT, and mTOR (mechanistic target of rapamycin) signaling pathway to stimulate protein synthesis ${ }^{53}$. Recent evidence also indicates that the positive effect of Mecp2 on mTOR is mediated by post-transcriptional processing of microRNAs that enhance mTOR activity so that Mecp2 depletion leads to a reduction in mTOR activity ${ }^{4}$.

IGF-1 administration has been reported to improve behavioral functional recovery in Mecp2-deficient mice (Mecp2 $2^{110 x /+}$ females $^{54}$ ) as well as spine density, synaptic amplitude, and PSD-95, a major constituent of the synaptic post-synaptic density in excitatory synapses ${ }^{55,56}$. Khwaja et al..$^{52}$ recently reported a preliminary assessment of the use of recombinant human IGF-1 (mecasermin) in girls with RTT. Some behavioral parameters, including anxiety and mood and an EEG parameter, seemed to improve, and the medication appeared to be safe and well tolerated ${ }^{52}$. Recent preclinical data suggest that fingolimod, a sphingosine-1 phosphate receptor modulator that can increase levels of BDNF, can also reduce signs of disease in a mouse model of RTT $^{57}$. Valproic acid has also recently been reported to have a positive behavioral effect on mice with Rett mutations and phenotype ${ }^{58}$.

\section{Conclusions}

Mice with Mecp2 deficiency display a variety of aberrant behaviors and synaptic abnormalities that correlate very well with those in human RTT. Girls with RTT and mice with Mecp2 deficiency display elevations in both glutamate and NMDA glutamate receptors and this is likely to produce abnormal homeostatic synaptic scaling and probably contributes to impaired activity-dependent synaptic plasticity. RTT appears to involve an imbalance between elevated glutamate levels and reduced GABA levels, similar to models of autism spectrum disorders. Chaotic sleep in mice with Mecp2 
deficiency has been shown to correlate with elevated baseline glutamate levels in the brain and very high elevations in glutamate associated with prolonged wakening. Several clinical studies are under way to attempt to normalize synaptic abnormalities in RTT, including the studies by Naidu et al. with dextromethorphan, a clinically approved competitive NMDA receptor blocker. A randomized un-blinded trial of dextromethorphan showed improvement in receptive language in girls with RTT, and a randomized trial of this drug is under way. Preclinical studies suggest that low-dose ketamine, a non-competitive NMDA blocker, might be useful for improving the connectivity of brain circuits affected in RTT and improving function. Human recombinant IGF-1 has also shown benefit in mice with Mecp2 deficiency, and a preliminary study in girls with RTT showed that it was well tolerated and may have some benefits.

\section{Competing interests}

The authors declare that they have no competing interests.

Grant information

This work was supported by FDA Grant 5RO1FD004247 and NIH-NICHD U54 HD079123.
1. Chen L, Chen K, Lavery LA, et al.: MeCP2 binds to non-CG methylated DNA as neurons mature, influencing transcription and the timing of onset for Rett syndrome. Proc Natl Acad Sci U S A. 2015; 112(17): 5509-14. PubMed Abstract | Publisher Full Text | Free Full Text

2. Naidu S, Johnston MV: Neurodevelopmental disorders: Clinical criteria for Ret syndrome. Nat Rev Neurol. 2011; 7(6): 312-4.

PubMed Abstract | Publisher Full Text

3. Chapleau CA, Larimore JL, Theibert A, et al:: Modulation of dendritic spine development and plasticity by BDNF and vesicular trafficking: fundamental roles in neurodevelopmental disorders associated with mental retardation and autism. J Neurodev Disord. 2009; 1(3): 185-96. PubMed Abstract | Publisher Full Text | Free Full Text

4. Tsujimura K, Irie K, Nakashima H, et al:: miR-199a Links MeCP2 with mTOR Signaling and Its Dysregulation Leads to Rett Syndrome Phenotypes. Cell Rep. 2015; 12(11): 1887-901.

PubMed Abstract | Publisher Full Text

5. Nectoux J, Fichou Y, Cagnard N, et al:: Cell cloning-based transcriptome analysis in cyclin-dependent kinase-like 5 mutation patients with severe epileptic encephalopathy. J Mol Med (Berl). 2011; 89(2): 193-202. PubMed Abstract | Publisher Full Text

6. Bahi-Buisson N, Nectoux J, Girard B, et al:: Revisiting the phenotype associated with FOXG1 mutations: two novel cases of congenital Rett variant. Neurogenetics. 2010; 11(2): 241-9. PubMed Abstract | Publisher Full Text

7. Fichou $\mathrm{Y}$, Bieth $\mathrm{E}$, Bahi-Buisson $\mathrm{N}$, et al:: Re: $C D K L 5$ mutations in boys with severe encephalopathy and early-onset intractable epilepsy. Neurology. 2009; 73(1): 77-8; author reply 78

PubMed Abstract | Publisher Full Text

8. Canitano R: New experimental treatments for core social domain in autism spectrum disorders. Front Pediatr. 2014; 2: 61 PubMed Abstract | Publisher Full Text | Free Full Text

9. Naidu S: Rett syndrome: a disorder affecting early brain growth. Ann Neurol. 1997; 42(1): 3-10.

PubMed Abstract | Publisher Full Text

10. Glaze DG: Rett syndrome: of girls and mice--lessons for regression in autism Ment Retard Dev Disabil Res Rev. 2004; 10(2): 154-8. PubMed Abstract | Publisher Full Text

11. Cooper RA, Kerr AM, Amos PM: Rett syndrome: critical examination of clinical features, serial EEG and video-monitoring in understanding and management Eur J Paediatr Neurol. 1998; 2(3): 127-35. PubMed Abstract | Publisher Full Text

12. de Felice $C$, Maffei S, Signorini C, et al: Subclinical myocardial dysfunction in Rett syndrome. Eur Heart J Cardiovasc Imaging. 2012; 13(4): 339-45. PubMed Abstract | Publisher Full Text

13. Jentarra GM, Olfers SL, Rice SG, et al:: Abnormalities of cell packing density and dendritic complexity in the MeCP2 A140V mouse model of Rett syndrome/X-linked mental retardation. BMC Neurosci. 2010; 11: 19. PubMed Abstract | Publisher Full Text | Free Full Text

14. Nguyen MV, Du F, Felice CA, et al:: MeCP2 is critical for maintaining mature neuronal networks and global brain anatomy during late stages of postnata brain development and in the mature adult brain. J Neurosci. 2012; 32(29): 10021-34

PubMed Abstract | Publisher Full Text | Free Full Text

15. Landi S, Putignano E, Boggio EM, et al.: The short-time structural plasticity of dendritic spines is altered in a model of Rett syndrome. Sci Rep. 2011;1:45. PubMed Abstract | Publisher Full Text | Free Full Text
16. Chapleau CA, Calfa GD, Lane MC, et al:: Dendritic spine pathologies in hippocampal pyramidal neurons from Rett syndrome brain and after expression of Rett-associated MECP2 mutations. Neurobiol Dis. 2009; 35(2): 219-33.

PubMed Abstract | Publisher Full Text | Free Full Text

17. Armstrong DD: Neuropathology of Rett syndrome. J Child Neurol. 2005; 20(9): 747-53.

PubMed Abstract | Publisher Full Text

18. Johnston MV, Jeon OH, Pevsner J, et al:: Neurobiology of Rett syndrome: a genetic disorder of synapse development. Brain Dev. 2001; 23(Suppl 1): S206-13.

PubMed Abstract | Publisher Full Text

19. Ronnett GV, Leopold D, Cai X, et al.: Olfactory biopsies demonstrate a defect in neuronal development in Rett's syndrome. Ann Neurol. 2003; 54(2): 206-18. PubMed Abstract | Publisher Full Text

20. Hamberger A, Gillberg C, Palm A, et al.: Elevated CSF glutamate in Rett syndrome. Neuropediatrics. 1992; 23(4): 212-3. PubMed Abstract | Publisher Full Text

21. Lappalainen R, Riikonen RS: High levels of cerebrospinal fluid glutamate in Rett syndrome. Pediatr Neurol. 1996; 15(3): 213-6. PubMed Abstract | Publisher Full Text

22. Blue ME, Naidu S, Johnston MV: Altered development of glutamate and GABA receptors in the basal ganglia of girls with Rett syndrome. Exp Neurol. 1999; 156(2): 345-52.

PubMed Abstract | Publisher Full Text

23. Blue ME, Naidu S, Johnston MV: Development of amino acid receptors in frontal cortex from girls with Rett syndrome. Ann Neurol. 1999; 45(4): 541-5. PubMed Abstract | Publisher Full Text

24. Horská A, Farage L, Bibat G, et al:: Brain metabolism in Rett syndrome: age, clinical, and genotype correlations. Ann Neurol. 2009; 65(1): 90-7. PubMed Abstract | Publisher Full Text | Free Full Text

25. Blue ME, Kaufmann WE, Bressler J, et al.: Temporal and regional alterations in NMDA receptor expression in Mecp2-null mice. Anat Rec (Hoboken). 2011; 294(10): 1624-34

PubMed Abstract | Publisher Full Text | Free Full Text

26. Blackman MP, Djukic B, Nelson SB, et al.: A critical and cell-autonomous role for MeCP2 in synaptic scaling up. J Neurosci. 2012; 32(39): 13529-36. PubMed Abstract | Publisher Full Text | Free Full Text

27. Asaka $Y$, Jugloff DG, Zhang L, et al:: Hippocampal synaptic plasticity is impaired in the Mecp2-null mouse model of Rett syndrome. Neurobiol Dis. 2006; 21(1): $217-27$.

PubMed Abstract | Publisher Full Text

28. Dani VS, Chang Q, Maffei A, et al:: Reduced cortical activity due to a shift in the balance between excitation and inhibition in a mouse model of Rett syndrome. Proc Natl Acad Sci U S A. 2005; 102(35): 12560-5. PubMed Abstract | Publisher Full Text | Free Full Text

29. Zhang L, He J, Jugloff DG, et al.: The MeCP2-null mouse hippocampus displays altered basal inhibitory rhythms and is prone to hyperexcitability. Hippocampus. 2008; 18(3): 294-309. PubMed Abstract | Publisher Full Tex

30. Maliszewska-Cyna E, Bawa D, Eubanks JH: Diminished prevalence but preserved synaptic distribution of $\mathrm{N}$-methyl-D-aspartate receptor subunits in the methyl $\mathrm{CpG}$ binding protein 2(MeCP2)-null mouse brain. Neuroscience. 2010; 168(3): 624-32.

PubMed Abstract | Publisher Full Text 
31. Magistretti PJ, Pellerin L: Cellular mechanisms of brain energy metabolism and their relevance to functional brain imaging. Philos Trans $R$ Soc Lond B Biol Sci. 1999; 354(1387): 1155-63.

PubMed Abstract | Publisher Full Text | Free Full Text

32. Zhou X, Hollern D, Liao J, et al:: NMDA receptor-mediated excitotoxicity depends on the coactivation of synaptic and extrasynaptic receptors. Cell Death Dis. 2013; 4(3): e560.

PubMed Abstract | Publisher Full Text | Free Full Text

33. Maezawa I, Jin LW: Rett syndrome microglia damage dendrites and synapses by the elevated release of glutamate. J Neurosci. 2010; 30(15): 5346-56. PubMed Abstract | Publisher Full Text

34. Guy J, Hendrich B, Holmes M, et al:: A mouse Mecp2-null mutation causes neurological symptoms that mimic Rett syndrome. Nat Genet. 2001; 27(3): 322-6.

PubMed Abstract | Publisher Full Text

35. Jin LW, Horiuchi M, Wulff $\mathrm{H}$, et al.: Dysregulation of glutamine transporter SNAT1 in Rett syndrome microglia: a mechanism for mitochondrial dysfunction and neurotoxicity. J Neurosci. 2015; 35(6): 2516-29. PubMed Abstract | Publisher Full Text | Free Full Text

36. Okabe $\mathrm{Y}$, Takahashi T, Mitsumasu $\mathrm{C}$, et al.: Alterations of gene expression and glutamate clearance in astrocytes derived from an MeCP2-null mouse model of Rett syndrome. PLoS One. 2012; 7(4): e35354. PubMed Abstract | Publisher Full Text | Free Full Text

37. Lioy DT, Garg SK, Monaghan CE, et al:: A role for glia in the progression of Rett's syndrome. Nature. 2011; 475(7357): 497-500. PubMed Abstract | Publisher Full Text | Free Full Text

38. Russell JC, Blue ME, Johnston MV, et al:: Enhanced cell death in MeCP2 null cerebellar granule neurons exposed to excitotoxicity and hypoxia. Neuroscience. 2007; 150(3): 563-74. PubMed Abstract | Publisher Full Text | Free Full Text

39. Azuma S, Kodama T, Honda K, et al: State-dependent changes of extracellular glutamate in the medial preoptic area in freely behaving rats. Neurosci Lett. 1996; 214(2-3): 179-82.

PubMed Abstract | Publisher Full Text

40. Johnston MV, Ammanuel S, O'Driscoll C, et al.: Twenty-four hour quantitative-EEG and in-vivo glutamate biosensor detects activity and circadian rhythm dependent biomarkers of pathogenesis in Mecp2 null mice. Front Syst Neurosci. 2014; 8: 118 .

PubMed Abstract | Publisher Full Text | Free Full Text

41. Chao HT, Chen H, Samaco RC, et al.: Dysfunction in GABA signalling mediates autism-like stereotypies and Rett syndrome phenotypes. Nature. 2010; 468(7321): 263-9.

PubMed Abstract | Publisher Full Text | Free Full Text

42. Kang SK, Kim ST, Johnston MV, et al.: Temporal- and Location-Specific Alterations of the GABA Recycling System in Mecp2 KO Mouse Brains. $J$ Cent Nerv Syst Dis. 2014; 6: 21-8.

PubMed Abstract | Publisher Full Text | Free Full Text

43. El-Khoury R, Panayotis N, Matagne V, et al: GABA and glutamate pathways are spatially and developmentally affected in the brain of Mecp2-deficient mice. PLoS One. 2014; 9(3): e92169.

PubMed Abstract | Publisher Full Text | Free Full Text

44. Nelson SB, Valakh V: Excitatory/Inhibitory Balance and Circuit Homeostasis in Autism Spectrum Disorders. Neuron. 2015; 87(4): 684-98. PubMed Abstract | Publisher Full Text | Free Full Text
45. Krishnan K, Wang BS, Lu J, et al.: MeCP2 regulates the timing of critical period plasticity that shapes functional connectivity in primary visual cortex. Proc Natl Acad Sci U S A. 2015; 112(34): E4782-91.

PubMed Abstract | Publisher Full Text | Free Full Text

46. Fagiolini M, Fritschy JM, Löw K, et al.: Specific GABAA circuits for visual cortical plasticity. Science. 2004; 303(5664): 1681-3.

PubMed Abstract | Publisher Full Text

47. Durand S, Patrizi A, Quast KB, et al:: NMDA receptor regulation prevents regression of visual cortical function in the absence of Mecp2. Neuron. 2012; 76(6): 1078-90.

PubMed Abstract | Publisher Full Text | Free Full Text

48. He LJ, Liu N, Cheng TL, et al:: Conditional deletion of Mecp2 in parvalbuminexpressing GABAergic cells results in the absence of critical period plasticity. Nat Commun. 2014; 5: 5036.

PubMed Abstract | Publisher Full Text

49. Kron M, Howell CJ, Adams IT, et al:: Brain activity mapping in Mecp2 mutant mice reveals functional deficits in forebrain circuits, including key nodes in the default mode network, that are reversed with ketamine treatment. $J$ Neurosci. 2012; 32(40): 13860-72.

PubMed Abstract | Publisher Full Text | Free Full Text

50. Slikker W Jr, Liu F, Rainosek SW, et al.: Ketamine-Induced Toxicity in Neurons Differentiated from Neural Stem Cells. Mol Neurobiol. 2015; 52(2): 959-69. PubMed Abstract | Publisher Full Text

51. McDonald JW, Johnston MV: Physiological and pathophysiological roles of excitatory amino acids during central nervous system development. Brain Res Brain Res Rev. 1990; 15(1): 41-70.

PubMed Abstract | Publisher Full Text

52. Khwaja OS, Ho E, Barnes KV, et al.: Safety, pharmacokinetics, and preliminary assessment of efficacy of mecasermin (recombinant human IGF-1) for the treatment of Rett syndrome. Proc Natl Acad Sci U S A. 2014; 111(12): 4596-601. PubMed Abstract | Publisher Full Text | Free Full Text

53. Banerjee A, Castro J, Sur M: Rett syndrome: genes, synapses, circuits, and therapeutics. Front Psychiatry. 2012; 3: 34.

PubMed Abstract | Publisher Full Text | Free Full Text

54. Chen RZ, Akbarian S, Tudor M, et al.: Deficiency of methyl-CpG binding protein-2 in CNS neurons results in a Rett-like phenotype in mice. Nat Genet. 2001; 27(3): 327-31.

PubMed Abstract | Publisher Full Text

55. Tropea D, Giacometti E, Wilson NR, et al: Partial reversal of Rett Syndrome-like symptoms in MeCP2 mutant mice. Proc Natl Acad Sci U S A. 2009; 106(6): 2029-34.

PubMed Abstract | Publisher Full Text | Free Full Text

56. Castro J, Garcia RI, Kwok S, et al:: Functional recovery with recombinant human IGF1 treatment in a mouse model of Rett Syndrome. Proc Natl Acad Sci U S A. 2014; 111(27): 9941-6.

PubMed Abstract | Publisher Full Text | Free Full Text

57. Deogracias R, Yazdani M, Dekkers MP, et al.: Fingolimod, a sphingosine-1 phosphate receptor modulator, increases BDNF levels and improves symptoms of a mouse model of Rett syndrome. Proc Natl Acad Sci U S A. 2012; 109(35): 14230-5.

PubMed Abstract | Publisher Full Text | Free Full Text

58. Guo W, Tsujimura K, Otsuka IM, et al.: VPA alleviates neurological deficits and restores gene expression in a mouse model of Rett syndrome. PLOS One. 2014; 9(6): e100215.

PubMed Abstract | Publisher Full Text | Free Full Text 


\section{Open Peer Review}

\section{Current Peer Review Status:}

\section{Editorial Note on the Review Process}

Faculty Reviews are review articles written by the prestigious Members of Faculty Opinions. The articles are commissioned and peer reviewed before publication to ensure that the final, published version is comprehensive and accessible. The reviewers who approved the final version are listed with their names and affiliations.

\section{The reviewers who approved this article are:}

\section{Version 1}

\section{Thierry Bienvenu}

AP-HP, Laboratoire de Biochimie et Génétique Moléculaire, AP-HP, Laboratoire de Biochimie et Génétique Moléculaire, GH Cochin-Broca-Hôtel Dieu, Paris, France and Université Paris Descartes Paris, Institut Cochin, INSERM U1016, Paris, France

Competing Interests: No competing interests were disclosed.

\section{Zhi-Qi Xiong}

Institute of Neuroscience, State Key Laboratory of Neuroscience, CAS Center for Excellence in Brain Science, Shanghai Institutes for Biological Sciences, Chinese Academy of Sciences, Shanghai, China Competing Interests: No competing interests were disclosed.

The benefits of publishing with F1000Research:

- Your article is published within days, with no editorial bias

- You can publish traditional articles, null/negative results, case reports, data notes and more

- The peer review process is transparent and collaborative

- Your article is indexed in PubMed after passing peer review

- Dedicated customer support at every stage

For pre-submission enquiries, contact research@f1000.com 